\title{
PENGARUH KOMPETENSI TERHADAP KINERJAPEGAWAI PADA PUSKESMAS KECAMATAN DARUSSALAM KABUPATEN ACEH BESAR
}

\author{
Syamsul Akmal \\ Program Studi Manajemen Fakultas Ekonomi Universitas Jabal Ghafur \\ E-mail syamsul_akmal24@yahoo.com
}

\begin{abstract}
This study aims to determine "The Influence of Competence on Employee Performance at Puskesmas Darussalam District, Aceh Besar District". Where the independent variables are Knowledge (X1), Skills (X2), Behavior (X3) and Work Experience (X4) and Employee Performance (Y) as the dependent variable. Population in this research is employee Puskesman District Darussalam. Samples were taken as many as 97 samples using saturated sampling technique (census). Data were collected using questionnaires filled out by respondents. The data obtained were analyzed by multiple linear regression. This analysis includes Test Validity, Reliability Test, Multiple Regression Analysis Test Classic Assumption, Hypothesis Testing through F Test and t Test , and Determination Coefficient analysis (R2). Based on the results of the study, obtained $Y=1.581+0.268 \mathrm{X} 1+0.232 \mathrm{X} 2+0.232 \mathrm{X} 3+0.430 \mathrm{X} 4$. Of the four variables studied, only the working experience variables (X4) has the most dominant effect of 0.430 to the Performance of employees at the Puskesmas Darussalam District, Aceh Besar District. The relationship of each Knowledge (X1), Skill (X2), Behavior (X3) and Work experience (X4) to the Performance of employees at Puskesmas Darussalam District, Aceh Besar Regency with correlation coefficient $(\mathrm{R})$ of 0.961 means that the relationship is very strong. Fcount $>$ Ftable at $95 \%$ confidence level $(\mathrm{a}=0.05)$, that is 175.092> 2.47. Then the coefficient of determination of each variable Knowledge (X1), Skills (X2), Behavior (X3) and Work Experience (X4) of 0.924 or $92.4 \%$ to Employee Performance (Y) means the four variables simultaneously affect Employee Performance on Puskesmas Darussalam District, Aceh Besar District, only 7,6\% influenced by other variable not examined in this research.
\end{abstract}

Keywords: Knowledge, Skills, Behavior, Work Experience and Performance

\section{PENDAHULUAN}

Peranan dan kedudukan Pegawai Negeri Sipil sangat penting dan menentukan karena pegawai negeri merupakan unsur aparatur negara dalam menyelenggarakan tugas-tugas pemerintahan dan pembangunan dalam rangka mencapai tujuan nasional. Anggaran Negara yang dibelanjakan untuk kepentingan pegawai negeri dari tahun ke tahun mengalami kenaikan, namun hal tersebut belum diimbangi dengan peningkatan profesionalisme dan integritas yang tinggi bagi komunitas Pegawai Negeri Sipil. Belanja pegawai adalah semua pengeluaran negara yang digunakan untuk membiayai kompensasi dalam bentuk uang atau barang yang diberikan kepada pegawai pemerintah pusat, pensiunan, anggota Tentara Nasional Indonesia/Kepolisian Negara Republik Indonesia, dan pejabat negara, baik yang bertugas di dalam negeri maupun di luar negeri, sebagai imbalan atas pekerjaan yang telah dilaksanakan, kecuali pekerjaan yang berkaitan dengan pembentukan modal.

Dalam upaya mengatasi permasalahan ini, para pengambil kebijakan dapat melakukan perbaikan kedalam, yang salah satunya melalui pengembangan sumber daya manusia. Perbaikan kondisi internal ini sekaligus bertujuan untuk memperkuat diri dan meningkatkan daya tahan dalam menghadapi persaingan lokal dan global yang pasti akan semakin ketat. Ini artinya instansi harus memperbaiki sistem manajemen kinerja instansinya melalui perbaikan kinerja pegawainya, karena keberhasilan instansi dalam memperbaiki kinerja instansinya sangat tergantung pada kualitas sumber daya manusia yang bersangkutan dalam berkarya atau bekerja.

Bekerja merupakan kegiatan manusia untuk mengubah keadaan tertentu dari suatu alam lingkungan. Perubahan ini ditujukan untuk memenuhi kebutuhan hidup dan memelihara hidup yang pada dasarnya untuk memenuhi tujuan hidup. Pada dasarnya kebutuhan hidup manusia tersebut tidak hanya berupa material, tetapi juga bersifat non-material seperti kebanggaan dan kepuasan kerja.

Kinerja adalah hasil atau tingkat keberhasilan seseorang secara keseluruhan selama periode tententu dalam melaksanakan tugas dibandingkan dengan berbagai 
kemungkinan, seperti standar hasil kerja, target atau sasaran maupun criteria yang ditentukan terlebih dahulu dan telah disepakati bersama. Jika dilihat dari asal katanya, kata kinerja berasal dari kata performance, berasal dari akar kata to perform yang mempunyai beberapa masukan (entries), yakni (1) melakukan, menjalankan, melaksanakan (to do or carry out execute); (2) memenuhi atau melaksanakan kewajiban suatu niat atau nazar (to dischange of fulfill; as vow); (3) melaksanakan atau menyempuranakan tanggung jawab (to execute or complete an understanding); (4) melakukan sesuatu yang diharapkan oleh seseorang atau mesin (to do what is expected of a person machine).

Kinerja dalam menjalankan fungsinya tidak berdiri sendiri, tetapi berhubungan dengan pengetahuan dan motivasi kerja. Oleh karena itu, ada dua faktor utama yang mempengaruhi kinerja individu yakni pengetahuan (ability), dan motivasi kerja (motivation) individu tesrbut. Pengetahuan individual tergantung dari tingkat pengetahuan (knowledge) yang dimiliki, latar belakang pendidikan, dan keterampilan (skill) yang dikuasai. Sedangkan motivasi kerja individual tergantung sikap (attitude) sebagai motivasi dasar dan lingkungan yang mempengaruhi motiviasi tersebut. Oleh karena itu, pembinaan dan peningkatan kinerja individu dapat dilakukan dengan pembinaan dan peningkatan pengetahuan dan motivasi kerja yang dimiliki.

Langkah antisipasi secara total yang diperlukan untuk menghasilkan lulusan yang mandiri, professional dan kompetitif tersebut maka perlu meingkatkan kinerja Pegawai Puskesmas Kecamatan Darussalam Kapuaten Pidie dengan penguasaan pengetahuan (cognitive), penguasaan keterampilan (psychomotoric), Pengembangan sikap mental (affective), dan Pengorientasian pada pekerjaan (transferability). Pengelolaan Puskesmas mutlak harus dilakukan dengan sebaik-baiknya mengingat dewasa ini Puskesmas di Indonesia diperhadapkan pada masa depan yang penuh tantangan, karena laju perubahan bergerak sangat cepat, tuntutan masyarakat semakin tinggi, kehidupan sanagat dipengaruhi oleh perkembangan ilmu pengetahuan dan teknologi, dan faktor-faktor lain yang kompleks dalam era globalisasi ini. Untuk mengetahui keadaan Pegawai Puskesmas Kecamatan Darussalam Kabupaten Aceh Besar maka dapat dilihat seperti tanel di bawah ini.
Tabel- I.1

Keadaan Pegawai Puskesmas Kecamatan

Darussalam Kabupaten Aceh Besar Tahun 2018

\begin{tabular}{|c|c|c|c|c|}
\hline No & $\begin{array}{c}\text { Pendidi } \\
\text { kan }\end{array}$ & Jumlah & $\begin{array}{c}\text { Pangkat/ } \\
\text { Golongan }\end{array}$ & Jumlah \\
\hline 2 & SLTA & 30 & IIa - IId & 30 \\
\hline 3 & D3 & 40 & IIIa - IIId & 65 \\
\hline 4 & Sarjana & 27 & IVa - IVd & 2 \\
\hline $\begin{array}{c}\text { Total } \\
\text { Pegawai }\end{array}$ & $\mathbf{9 7}$ & & $\mathbf{9 7}$ \\
\hline
\end{tabular}

Sumber: Bagian Tata Usaha Puskesmas

Kecamatan Darussalam (2018)

Puskesmas Kecamatan Darussalam

Kabupaten Aceh Besar sebagai salah satu Puskesmas dalam menjalankan tugas dan fungsinya selalu mengacu pada kode etik dan peraturan-peraturan yang berlaku sebgai kunci kesuksesan Puskesmas dalam menjalankan tugasnya sebagai pelayan publik. Kinerja individu adalah hasil kerja pegawai baik dari segi kualitas maupun kuantitas berdasarkan standar kerja yang telah ditentukan. Pegawai yang produktif menggambarkan potensi, persepsi dan kreativitas seseorang yang senantiasa dapat menyumbangkan pengetahuan agar bermanfaat bagi diri dan lingkungannya. Pengembangan komptensi dapat dilakukan dengan pembinaan dalam peningkatan pengetahuan dan motivasi kerja yang dimiliki. Peningkatan pengetahuan kerja dilakukan dengan upaya peningkatan aspek-aspek yang mendasari unsur tersebut yakni pengetahuan dan keterampilan kerja individu serta peningkatan motivasi kerja dilakukan dengan cara membina sikap mental individu serta situasi/lingkungan yang mendorong timbulnya kepuasan dan kemauan kerja individu.

Selama ini penilaian prestasi kinerja pegawai menggunakan Daftar Penilaian Pelaksanaan Pekerjaan (DP3) yang di dalamnya terdapat 8 (delapan) unsur, yaitu kejujuran, kesetiaan, ketaatan, prestasi kerja, tanggung jawab, kerjasama, kepemimpinan dan prakarsa. Harapan terhadap profesionalisme pegawai ini dilatarbelakangi oleh adanya kesenjangan antara kinerja yang diharapakan (intended performace) dengan kinerja nyata yang dihasilkan (actual performance) oleh pegawai. Masih banyaknya tingkat inefisiensi dalam pelaksanaan tugas merupakan bukti nyata kompetensi yang masih 
rendah.Pegawai yang kurang profesional dan kurang memiliki kesadaran moral cenderung melakukan penyalahgunaan wewenang atau penyalahgunaan keuangan negara. Perilaku pegawai yang menyimpang tersebut akan menjadi permasalahan yang rumit, manakala pegawai belum mampu beradaptasi dengan dinamika perubahan lingkungan termasuk kurang peka menghadapi perkembangan ilmu pengetahuan dan teknologi serta sulit untuk memperbaiki kinerjanya.

Dalam pengamatan penulis pada Instansi Puskesmas Kecamatan Darussalam sebagai instansi kesehatan profesional di Kecamatan Darussalam seharusnya bisa menjadi barometer dalam pencapaian kinerja yang tinggi. Namun, kenyataan empiris menunjukkan bahwa kinerja pegawai tidak maksimal.

Berdasarkan uraian tersebut, penulis merasa tertarik untuk melakukan penelitian dengan melanjutkan penelitian terdahulu juga oleh penulis mengenai kompetensi dan kinerja pegawai pada Puskesmas Kecamatan Darussalam Kabupaten Aceh Besar dan pada penelitian ini, penulis dengan judul "Pengaruh Kompetensi Terhadap Kinerja Pegawai Pada Puskesmas Kecamatan Darussalam Kabupaten Aceh Besar".

\section{Rumusan Masalah}

Berdasarkan latar belakang diatas, penulis merumuskan permasalahan sebagai berikut :

1. Bagaimanakah pengaruh pengetahuan, keterampilan, perilaku, dan pengalaman kerja terhadap Kinerja Pegawai Puskesmas Kecamatan Darussalam Kabupaten Aceh Besar?

2. Variabel manakah yang paling dominan berpengaruh terhadap kinerja pegawai Puskesmas Kecamatan Darussalam Kabupaten Aceh Besar?

\section{Tujuan Penelitian}

Adapun tujuan penelitian ini adalah :

1. Untuk mengetahui pengaruh pengetahuan, keterampilan, perilaku dan pengalaman kerja terhadap Kinerja Pegawai Puskesmas Kecamatan Darussalam Kabupaten Aceh Besar.

2. Untuk mengetahui variabel yang paling dominan mempengaruhi kinerja
pegawaiPuskesmas Kecamatan Darussalam Kabupaten Aceh Besar.

\section{Manfaat/kegunaan Penelitian}

Adapun manfaat/kegunaan penelitian ini adalah:

1. Dapat memperkaya pengetahuan mengenai kompetensi dan kinerja pegawai.

2. Dapat menjadi referensi bagi peneliti selanjutnya yang menyangkut kompetensi dan kinerja pegawai.

3. Dapat menyumbangkan saran-saran untuk meningkatkan kompetensi pegawai, kinerja pegawai dan kinerja organisasi pada Puskesmas Kecamatan Darussalam.

\section{STUDI KEPUSTAKAAN \\ Kompetensi \\ Pengertian Kompetensi}

Menurut Amstrong \& Murlis (2008:47), kompetensi sebagai karakteristik mendasar individu yang secara kausal berhubungan dengan efektivitas atau kinerja yang sangat baik

Selanjutnya menurut Wahjosumidjo (2005:24) kompetensi adalah

"Kinerja tugas rutin yang integratif, yang menggabungkan resources (kemampuan, pengetahuan, asset dan proses, baik yang terlihat maupun yang tidak terlihat) yang menghasilkan posisi yang lebih tinggi dan kompetitif. Sebagai konsekuensi dari defenisi kompeten atau kompetensi ini, atau yang lain maka pengertian kompetensi merujuk pada kemampuan orang untuk memenuhi persyaratan perannya saat ini atau masa mendatang”.

Menurut Sutrisno (2009:85) kompetensi merupakan landasan dasar karakteristik orang dan mengindikasikan cara berperilaku atau berpikir, menyamakan situasi, dan mendukung untuk periode waktu cukup lama.

Sanusi (2011:93) mengatakan bahwa kompetensi adalah keseluruhan pengetahuan, keterampilan, perilaku, dan sikap yang ditampilkan oleh orang-orang yang sukses/berhasil dalam mengerjakan suatu tugas dengan prestasi kerja.

Menurut Amstrong (Moeheriono, 2012:6) kompetensi adalah dimensi tindakan dari tugas, dimana tindakan tersebut dipakai oleh karyawan untuk menyelesaikan tugas pekerjaan mereka dengan memuaskan dan apa yang diberikan karyawan dalam bentuk yang berbeda-beda dan tingkatan kinerjanya. 
Menurut Spencer dalam Sudarmanto, (2009:53) mengemukakan komponenkomponen kompetensi mencakup ; motive, traits, self concept, knowledge, dan skill. Selanjutnya Spencer dalam Moeheriono, (2012:10), hubungan antara kompetensi karyawan dengan kinerja adalah sangat erat dan penting sekali, relevansinya ada dan kuat akurat, bahkan mereka apabila ingin meningkatkan kinerjanya seharusnya mempunyai kompetensi yang sesuai dengan tugas pekerjaannya (the right man on the right job). Hasil penelitian Zaim, et.al (2012:961) menunjukkan kompetensi mempunyai hubungan dengan kinerja. Demikian pula hasil penelitian Bismark, et.al (2012:7) menunjukkan kompetensi berpengaruh terhadap kinerja.

Ruky (2006:104) mengutip pendapat Spencer \&Spencer dari kelompok konsultan Hay \& Mac Ber bahwa Kompetensi adalah "an underlying characteristic of an individual that is casually related to criterion-referenced effective and/or superior performance in a job or situation"

Susanto (2008:123) memberikan batasan bahwa kompetensi adalah segala bentuk perwujudan, ekspresi, dan representasi dari motif, pengetahuan, sikap, perilaku utama agar mampu melaksanakan pekerjaan dengan sangat baik atau yangmembedakan antara kinerja rata-rata dengan kinerja superior.Pendekatan ini dilihat dari sudut pandang inidividual.

Lebih lanjut Ruky (2006:106) mengungkapkan bahwa kompetensi merupakan kombinasi dari keterampilan (skill), pengetahuan (knowledge), dan perilaku (attitude) yang dapat diamati dan diterapkan secara kritis untuk suksesnya sebuah organisasi dan prestasi kerja serta kontribusi pribadi pegawai terhadap organisasinya.

\section{Komponen Utama Kompetensi}

Prihadi (2006:17) mengatakan bahwa komponen utama kompetensi adalah seperangkat pengetahuan, keterampilan, dan sikap yang saling terkait mempengaruhi sebagian besar jabatan (peranan atau tanggung jawab), berkolerasi dengan kinerja pada jabatan tersebut, dan dapat diukur dengan standarstandar yang dapat diterima, serta dapat ditingkatkan melalui upaya-upaya pelatihan dan pengembangan.
Kemudian Hutapea dan Thoha (2008:28) mengungkapkan bahwa ada empat komponen utama pembentukan kompetensi yaitu pengetahuan yang dimiliki seseorang, kemampuan, pengalaman, dan perilaku individu.

Keempat komponen utama dalam kompetensi dapat dijelaskan lebih rinci sebagai berikut :

1. Pengetahuan

Pengetahuan adalah informasi yang dimiliki oleh seseorang.Pengetahuan adalah komponen utama kompetensi yang mudah diperoleh dan mudah diidentifikasi. Yuniarsih dan Suwatno (2008:23) bahwa : "Pengetahuan adalah suatu informasi yang dimiliki seseorang khususnya pada bidang spesifik."

Dapat disimpulkan bahwa pegawai yang berpengetahuan kurang, akan mengurangi efisiensi. Maka dari itu, pegawai yang berpengetahuan kurang harus diperbaiki dan dikembangkan melalui pelatihan SDM, agar tidak merugikan usahausaha pencapaian tujuan organisasi yang sudah ditentukan sebelumnya. Pengetahuan dikategorikan sebagai berikut :

a. Informasi yang didapatkan dan diletakkan dalam ingatan kita (Deklaratif).

b. Bagaimana informasi dikumpulkan dan digunakan ke sesuatu hal yang sudah kita ketahui (Procedural).

c. Mengerti tentang how, when dan why informasi tersebut berguna dan dapat digunakan (Strategic).

\section{Keterampilan}

Menurut Dunnett's

$(2007: 105)$ ketrampilan adalah sebagai kapasitas yang dibutuhkan untuk melaksanakan suatu rangkaian tugas yang berkembang dari hasil pelatihan dan pengalaman.

Menurut Yuniarsih dan Suwatno (2008:23) bahwa : "Keterampilan (skill) merupakan kemampuan untuk mampu melaksanakan tugas-tugas fisik dan mental"

3. Perilaku

Apabila pegawai mempunyai sifat yang mendukung pencapaian tujuan organisasi, maka secara otomatis segala tugas yang dibebankan kepadanya akan dilaksanakan dengan sebaik-baiknya. 
Menurut Gitosudarmo dan Sudita (2008:23) mengemukakan bahwa : "Perilaku kerja adalah sikap keteraturan perasaan dan pikiran seseorang dan kecenderungan bertindak terhadap aspek lingkungannya."

\section{Pengalaman Kerja}

Banyak perusahaan atau organisasi yang kerap kali menganggap bahwa pengalaman sebgai indikator yang tepat dari kemampuan dan sikap yang berhubungan dengan pekerjaan.Pengalaman adalah keseluruhan pelajaran yang diperoleh seseorang dari peristiwa-peristiwa yang dialami dalam perjalanan hidup.Pengalaman yang dapat membentuk kompetensi sesorang misalnya pengalaman yang diperoleh dari bekerja dan berorganisasi. Baik pengalaman manis maupun pahit berperan penting dalam pembentukan kompetensi dari individu. Mengingat pengalaman sesorang memiliki peran yang cukup besar dalam pembentukan kompetensi, maka sudah sewajarnya seorang pemimpin mengetahui latar belakang sumber daya manusianya.

Menurut Manullang

(2008:84) pengalaman kerja adalah "proses pembentukan pengetahuan atau keterampilan tentang metode suatu pekerjaan karena keterlibatan pegawai tersebut dalam pelaksanaan tugas pekerjaan".

Sedangkan Knoers dan Hadinoto (2008:19) mengemukakan bahwa: "Pengalaman kerja adalah sebagai suatu proses pembelajaran dan pertambahan perkembangan potensi bertingkah laku baik dari pendidikan formal maupun non formal atau bisa diartikan sebagai suatu proses yang membawa seseorang kepada suatu pola tingkah laku yang lebih tinggi."

$$
\text { Selanjutnya Sudarmanto }
$$
mengemukakan bahwa komponen-komponen kompetensi terdiri dari motive (dorongan), traits (ciri, sifat, karakter pembawaan), self image (citra diri), social role (peran sosial), dan skills (keterampilan).

\section{Ciri-ciri Kompetensi}

Menurut Sutrisno (2009:85) kompetensi merupakan landasan dasar karakteristik orang dan mengindikasikan cara berperilaku atau berpikir, menyamakan situasi, dan mendukung untuk periode waktu cukup lama.

Menurut Sutrisno (2009:85) ada lima karakteristik kompetensi, yaitu sebagai berikut :

a. Motif (Motive),apa yang secara konsisten dipikirkan atau keinginan-keinginan yang menyebabkan melakukan tindakan. Apa yang mendorong perilaku mengarah dan dipilih terhadap kegiatan atau tujuan tertentu. Contoh motif berprestasi akan memotivasi orang-orang secara terus menerus untuk merancang tujuan yang cukup menantang serta mengambil tanggung jawab atas pekerjaannya dan menggunakan umpan balik untuk menjadi lebih baik.

b. Sifat/coro bawaan (Trait), ciri fisik dan reaksi-reaksi yang bersifat konsisten terhadap situasi atau informasi. Contoh, reaksi waktu, luas pandangan yang baik merupakan kompetensi bagi seorang pilot.

c. Konsep diri (Self concept), sikap, nilai atau self image dari orang-orang. Contoh, percaya diri (self confidence), keyakinan bahwa ia akan efektif dalam berbagai situasi, merupakan bagian dari konsep dirinya.

d. Pengetahuan (Knowledge), yaitu suatu informasi yang dimiliki seseorang khususnya pada bidang spesifik. Pengetahuan merupakan kompetensi yang kompleks.Biasanya tes pengetahuan mengukur kemampuan untuk memilih jawaban yang paling benar, tetapi tidak bisa melihat apakah sesorang dapat melakukan pekerjaan berdasarkan pengetahuan yang dimilikinya itu.

e. Keterampilan (Skill), kemampuan untuk mampu melaksanakan tugas-tugas fisik dan mental tertentu. Contohnya seorang dokter gigi memiliki kemampuan menambal dan mencabut gigi tanpa merusak syaraf.

\section{Kinerja Pegawai \\ Pengertian Kinerja Pegawai}

Kinerja merupakan suatu fungsi dari motivasi dan kemampuan.Untuk menyelesaikan tugas atau pekerjaan seseorang sepatutnya memiliki derajat kesediaan dan tingkat kemampuan tertentu. Kesediaan dan keterampilan seseorang tidaklah cukup efektif untuk mengerjakan sesuatu tanpa pemahaman yang jelas tentang apa yang akan dikerjakan dan bagaimana mengerjakannya. Kinerja merupakan perilaku nyata yang ditampilkan setiap orang sebagai prestasi kerja yang dihasilkan oleh pegawai sesuai dengan perannya dalam perusahaan.Kinerja pegawai merupakan suatu hal yang sangat penting dalam upaya perusahaan untuk mencapai tujuannya.

Oleh karena itu dapat disimpulkan bahwa kinerja sumber daya manusia adalah prestasi 
kerja atau hasil kerja (output) baik kualitas maupun kuantitas yang dicapai sumber daya manusia persatuan periode waktu dalam melaksakan tugas kerjanya sesuai dengan tanggung jawab yang diberikan kepadanya.

Yuli (2005:89) mengemukakan bahwa : "Kinerja adalah hasil kerja secara kualitas dan kuantitas yang dicapai oleh seorang pegawai dalam melaksanakan tugasnya sesuai dengan tanggug jawab yang diberikan kepadanya.

Selanjutnya Malthis dan Jackson (2006:378) mengemukakan bahwa : "Kinerja pegawai pada dasarnya adalah apa yang dilakukan atau tidak dilakukan oleh pegawai."

Sedangkan menurut Ruky (2006:15) mengemukakan bahwa: "Kinerja adalah catatan tentang hasil-hasil yang diperoleh dai fungsifungsi pekerjaan tertentu atau kegiatan tertentu selama kurun waktu tertentu."

Kinerja pegawai merupakan gabungan dari tiga faktor penting yaitu kemampuan dan minat seorang pekerja kemampuan dan penerimaan atas penjelasan delegasi tugas, serta peran dan tingkat motivasi seorang pekerja.Semakin tinggi dari ketiga faktor di atas, semakin besarlah prestasi kerja pegawai bersangkutan.

Mangkunegara (2008:9) menyatakan bahwa : "Kinerja pegawai (prestasi kerja) adalah hasil kerja secara kualitas dan kuantitas yang dicapai oleh seseorang pegawai dalam melaksanakan tugasnya sesuai dengan tanggung jawab yang diberikan kepadanya."

\section{Penilaian Kinerja Pegawai}

"Penilaian kinerja merupakan proses subjektif yang menyangkut penilaian manusia. Dengan demikian, penilaian kinerja sangat mungkin keliru dan sangat mudah dipengaruhi oleh sumber yang tidak aktual. Tidak sedikit sumber tersebut mempengaruhi proses penilaian, sehingga harus diperhitungkan dan dipertimbangkan dengan wajar. Penilaian kinerja dianggap memenuhi sasaran apabila memiliki dampak yang baik pada tenaga kerja yang abru dinilai kinerja/keragaannya" (Dessler, 2008:7).

Penilaian kinerja berbicara tentang kinerja pegawai dan akuntabilitas.Di tengah kompetisi global, perusahaan menuntut kinerja yang tinggi.
Seiring dengan itu, kalangan pegawai membutuhkan umpan balik atas kinerja mereka sebagai pedoman perilakunya di masa depan.

\section{METODE PENELITIAN}

\section{Lokasi dan Objek Penelitian}

Penelitian ini dilaksanakan di Puskesmas Kecamatan Darussalam Kabupaten Aceh Besar. Objek penelitiannya adalah "Kompetensi dan Kinerja Pegawai”.

\section{Populasi dan Sampel \\ Populasi}

Populasi adalah wilayah generalisasi yang terdiri atas obyek/subyek yang mempunyai kualitas dan karakteristik tertentu yang ditetapkan oleh peneliti untuk dipelajari dan kemudian ditarik kesimpulannya (Sugiyono, 2009:90). Dalam penelitian ini yang menjadi populasi adalah seluruh pegawai Puskesmas Kecamatan Darussalam yang berjumlah 97 orang.

\section{Sampel}

Menurut Arikunto (2010 :134-185) "Sampel adalah sebagian atau wakil populasi yang diteliti. Apabila populasi penelitian berjumlah kurang dari 100 maka sampel yang diambil adalah semuanya, namun apabila populasi penelitian berjumlah lebih dari 100 maka sampel dapat di ambil antara $10-15 \%$ atau 20-25\% atau lebih.“. Karena jumlah populasi dalam penelitian ini kurang dari 100, maka akan diteliti seluruhnya yang berjumlah 97 orang.

\section{Jenis dan Sumber Data Data Primer}

Data primer adalah data yang diperoleh melalui hasil penelitian langsung terhadap obyek yang diteliti.Data tersebut diperoleh melalui metode wawancara, observasi dan kuesioner dari responden yaitu Pegawai pada Puskesmas Kecamatan Darussalam Kabupaten Aceh Besar.

\section{Data Sekunder}

Data Sekunder adalah data yang diperoleh dari berbagai sumber antara lain dari dokumentasi/tulisan (buku-buku, laporan- 
laporan, karya ilmiah dan hasil penelitian) dan dari informasi pihak-pihak yang berkaitan dengan kajian yang diteliti (uraian tugas, tata kerja dan referensi lainnya).

\section{Teknik Pengumpulan Data}

Proses pengumpulan data yang diperlukan dalam pembahasan inimelalui dua tahap penelitian, yaitu:

1. Studi Kepustakaan (Library Research)

Studi kepustakaan digunakan untuk mengumpulkan data sekunder, landasan teori dan informasi yang berkaitan dengan penelitian ini dengan cara dokumentasi. Studi dilakukan antara lain dengan mengumpulkan data yang bersumber dari literatur-literaturdan hasil penelitian lainnya yang ada hubungannya dengan objek penelitian. Hal ini dilakukan untuk mendapatkan tambahan pengetahuan mengenai masalah yang sedang diteliti.

\section{Studi Lapangan (Field Research)}

Dalam penelitian ini penulis mengumpulkan data yang diperlukan dengan cara melakukan pengamatan langsung pada instansi yang bersangkutan, baik melalui wawancara dan penyebaran kuesioner kepada para pegawai.

Penelitian lapangan dilakukan dengan cara :

a. Wawancara adalah metode untuk mendapatkan data dengan cara melakukan tanya jawab secara langsung dengan pihak-pihak yang bersangkutan guna mendapatkan data dan keterangan yang menunjang analisis dalam penelitian.

b. Kuesioner, adalah pengumpulan data dengan cara menyebarkan daftar pernyataan yang telah di format khusus kepada responden, untuk diberikan indikasi setuju atau tidak setuju terhadap pernyataan tersebut.

\section{Skala Pengukuran Variabel}

Menurut Sugiyono (2010 : 132) skala likert digunakan untuk mengukur sikap, pendapat, dan persepsi seseorang atau kelompok orang tentang fenomena sosial. Data hasil penelitian yang diperoleh melalui penyebaran kuesioner dalam bentuk kualitatif dikomposisikan terlebih dahulu agar menjadi data kuantitatif.Adapun nilai kuantitatif yang dikomposisikan dilakukan dengan menggunakan Skala Likert dan untuk satu pilihan dinilai dengan jarak interval 1 . Nilai dari pilihan tersebut antara lain : 1,2,3,4, dan 5. Masingmasing pilihan tersebut dapat dilihat dalam tabel dibawah ini :

Tabel-III.1

Skala Likert

\begin{tabular}{|l|c|}
\hline \multicolumn{1}{|c|}{ Keterangan (pilihan) } & Skor \\
\hline Sangat Tidak Setuju & 1 \\
Tidak Setuju & 2 \\
Kurang Setuju & 3 \\
Setuju & 4 \\
Sangat Setuju & 5 \\
\hline
\end{tabular}

\section{Peralatan Analisis Data}

Dalam penelitian ini, analisis regresi berganda berperan sebagai teknik statistik yang digunakan untuk menguji ada tidaknya pengaruh pengetahuan, keterampilan, perilaku dan pengalaman kerja terhadap Kinerja Pegawai. Analisis regresi menggunakan rumus persamaan regresi berganda seperti yang dikutip dari buku Riduwan dan Akdon (2007 : 142), yaitu : $\mathrm{Y}=\mathrm{b} 1 \mathrm{X} 1+\mathrm{b} 2 \mathrm{X} 2+\mathrm{b} 3 \mathrm{X} 3+\mathrm{b} 4 \mathrm{X} 4+\mathrm{ei}$

$\mathrm{Y}=$ Kinerja

$\mathrm{X}=$ Pengetahuan

$\mathrm{X} 2=$ Keterampilan

$\mathrm{X} 3=$ Perilaku

$\mathrm{X} 4=$ Pengalaman Kerja

$\mathrm{b} 1=$ Koefesien Regresi (Pengetahuan)

b2 $=$ Koefisien Regresi (Keterampilan)

b3 $=$ Koefisien Regresi (Perilaku)

b4 $=$ Koefisien Regresi (Pengalaman Kerja)

$\mathrm{e} i=\quad$ Faktor Kesalahan (Error)

\section{Definisi dan Operasional Variabel}

Adapun operasional variabel dalam penelitian ini adalah : 
Tabel-III.2

Definisi Operasional Variabel

\begin{tabular}{|c|c|c|c|c|c|}
\hline Vinated & bet & lasebat & Latin & Sa.s & $\begin{array}{l}\text { Lich } \\
\text { fersa } \\
\text { Eissa }\end{array}$ \\
\hline $\begin{array}{c}\text { Fergetxhuse } \\
\left(x_{i}\right)\end{array}$ & 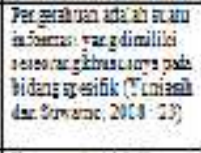 & 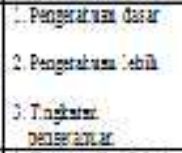 & $\begin{array}{l}-5 \\
-5 \\
-5\end{array}$ & 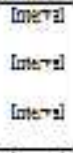 & \begin{tabular}{|l}
$x 1:$ \\
812 \\
xIs
\end{tabular} \\
\hline $\begin{array}{c}\text { Eeterawziha } \\
\qquad \alpha i\end{array}$ & 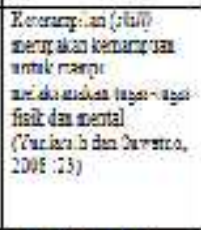 & 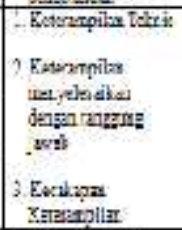 & $\begin{array}{l}\therefore-2 \\
\therefore-5\end{array}$ & $\begin{array}{l}\text { Imotal } \\
\text { Lueval } \\
\text { Lneาa! }\end{array}$ & $\begin{array}{l}\text { N: } \\
\text { nis } \\
\text { nis }\end{array}$ \\
\hline Perilala ( $\boldsymbol{X}$ ) & 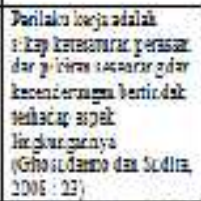 & 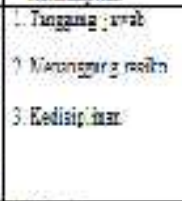 & $\begin{array}{l}-5 \\
-5 \\
-5\end{array}$ & 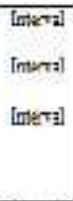 & $\begin{array}{l}9: 2 \\
2: 3 \\
8: 3\end{array}$ \\
\hline 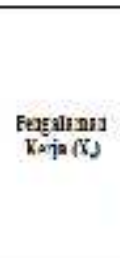 & 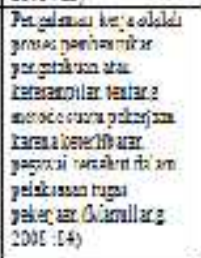 & 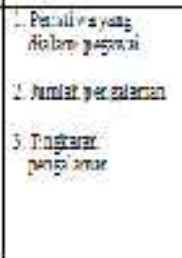 & $\begin{array}{l}-5 \\
\therefore-5\end{array}$ & $\begin{array}{l}\text { Luerd } \\
\text { Lmeral } \\
\text { Lmexal }\end{array}$ & 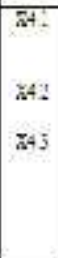 \\
\hline$\underset{\text { Pesama (Q) }}{\text { Eivtjo }}$ & 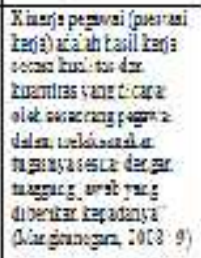 & 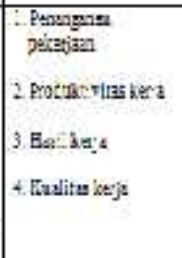 & $\begin{array}{l}-5 \\
\therefore 5 \\
-5 \\
\therefore 5\end{array}$ & 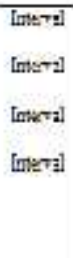 & $\begin{array}{l}r: \\
n \\
r \\
i\end{array}$ \\
\hline
\end{tabular}

\section{HASIL PENELITIAN \\ Karakteristik Responde}

Karakteristik responden yang diteliti dalam penelitian ini adalah mencakup jenis kelamin, usia, pendidikan terakhir, pekerjaan, dan pendapatan responden. Hasil pengelolaan data melalui proses komputerisasi dengan program SPSS yang ditunjukkan pada Tabel 4.1 dibawah ini :

Tabel-IV.1

Karakteristik Responden

\begin{tabular}{|c|c|c|c|}
\hline No & Uraian & Frekuensi & $\begin{array}{c}\text { Persenta } \\
\text { se }\end{array}$ \\
\hline 1. & $\begin{array}{l}\text { Jenis Kelamin } \\
\text { Laki-laki } \\
\text { Perempuan }\end{array}$ & $\begin{array}{l}21 \text { orang } \\
76 \text { orang }\end{array}$ & $\begin{array}{l}21,6 \% \\
78,4 \%\end{array}$ \\
\hline 2. & $\begin{array}{l}\text { Usia } \\
<25 \text { tahun } \\
26-30 \text { tahun } \\
31-35 \text { tahun } \\
36-40 \text { tahun } \\
>41 \text { tahun }\end{array}$ & $\begin{array}{c}\text { - } \\
24 \text { orang } \\
25 \text { orang } \\
21 \text { orang } \\
27 \text { orang }\end{array}$ & $\begin{array}{c}- \\
24,7 \% \\
25,8 \% \\
21,6 \% \\
27,8 \%\end{array}$ \\
\hline
\end{tabular}

\begin{tabular}{|c|c|c|c|}
\hline 3. & $\begin{array}{l}\text { Pendidikan Terakhir } \\
\text { SLTA } \\
\text { Diploma } 3 \\
\text { Sarjana } \\
\text { Pasca Sarjana }\end{array}$ & $\begin{array}{c}30 \text { orang } \\
40 \text { orang } \\
27 \text { orang } \\
-\end{array}$ & $\begin{array}{c}30,9 \% \\
41,2 \% \\
27,8 \%\end{array}$ \\
\hline 4. & $\begin{array}{l}\text { Masa Kerja } \\
<2 \text { tahun } \\
2-5 \text { tahun } \\
5-10 \text { tahun } \\
>10 \text { tahun }\end{array}$ & $\begin{array}{c}- \\
32 \text { orang } \\
46 \text { orang } \\
19 \text { orang }\end{array}$ & $\begin{array}{c}- \\
33,0 \% \\
47,4 \% \\
19,6 \%\end{array}$ \\
\hline
\end{tabular}

Sumber : Data Primer Diolah (2018)

Berdasarkan hasil penelitian dari tabel dapat dijelaskan bahwa karakteristik responden berdasarkan jenis kelamin dapat dijelaskan bahwa responden laki-laki sebanyak $21,6 \%$ dan responden perempuan sebanyak $78,4 \%$ dari total sampel yang diteliti. Karakteristik berdasarkan tingkat usia dapat dijelaskan bahwa sebanyak $24,7 \%$ pada usia 26-30 tahun, sebanyak $25,8 \%$ berusia antara 31-35 tahun dan sebanyak 21,6 \%berusia 36-40 tahun danpada usia $>41$ tahun, sebanyak 27,8 \%dari total responden yang diteliti.

Mengenai tingkat pendidikan terakhir responden, dapat dijelaskan bahwa sebnyak 30,9 $\%$ berpendidikan terakhir SLTA, sebanyak 41,2 $\%$ berpendidikan terakhir Diploma-3 dan sebanyak 27,8 \% berpendidikan Sarjana dari total sampel.

Karakteristik berdasarkan masa kerja menunjukkan bahwa $33,0 \%$ sudah bekerja selama 2-5 tahun, sebanyak 47,4 \% sudah bekerja selama 5-10 tahun dan sebanyak 19,6\% sudah bekerja selama $>10$ tahun dari total sampel.

\section{Uji Validitas dan Reliabilitas Uji Validitas}

Pengujian validitas butir-butir dari kuesioner ini dilakukan secara statistik, yaitu mengunakan metode korelasi product moment, dengan kriteria penentuan jika koefisien korelasi (r) yang diperoleh lebih besar dari pada koefisien dari tabel nilai-nilai kritis $r$, yaitu pada taraf sinifikan 5\%.

Nilai rtabel untuk penelitian ini adalah 0.198.Jika rhitung lebih besar dari rtabel maka kuesioner dikatakan valid dan sebaliknya jika rhitung lebih kecil dari rtabel maka kuesioner tersebut dikatakan tidak valid sebagai instrumen penelitian. Adapun hasil uji tersebut adalah sebagai berikut : 
Tabel-IV.2

Hasil Uji Validitas

\begin{tabular}{|c|c|c|c|c|}
\hline $\begin{array}{c}\text { Vari } \\
\text { abel }\end{array}$ & $\begin{array}{c}\text { Pertany } \\
\text { aan }\end{array}$ & $\begin{array}{c}\text { Koefisien } \\
\text { Korelasi }\end{array}$ & $\begin{array}{c}\text { Nilai Kritis }= \\
5 \%(97)\end{array}$ & Ket \\
\hline \multirow{3}{*}{$\mathrm{X}_{1}$} & $\mathrm{X} 1.1$ & 0,783 & 0.198 & Valid \\
\cline { 2 - 5 } & $\mathrm{X} 1.2$ & 0,833 & 0.198 & Valid \\
\cline { 2 - 5 } & $\mathrm{X} 1.3$ & 0,674 & 0.198 & Valid \\
\hline \multirow{3}{*}{$\mathrm{X}_{2}$} & $\mathrm{X} 2.1$ & 0,714 & 0.198 & Valid \\
\cline { 2 - 5 } & $\mathrm{X} 2.2$ & 0,855 & 0.198 & Valid \\
\cline { 2 - 5 } & $\mathrm{X} 2.3$ & 0,734 & 0.198 & Valid \\
\hline \multirow{3}{*}{$\mathrm{X}_{3}$} & $\mathrm{X} 3.1$ & 0,805 & 0.198 & Valid \\
\cline { 2 - 5 } & $\mathrm{X} 3.2$ & 0,790 & 0.198 & Valid \\
\cline { 2 - 5 } $\mathrm{X}_{4}$ & $\mathrm{X} 3.3$ & 0,820 & 0.198 & Valid \\
\hline \multirow{3}{*}{$\mathrm{Y}$} & $\mathrm{X} 4.1$ & 0,666 & 0.198 & Valid \\
\cline { 2 - 5 } & $\mathrm{X} 4.2$ & 0,777 & 0.198 & Valid \\
\cline { 2 - 5 } & $\mathrm{X} 4.3$ & 0,727 & 0.198 & Valid \\
\hline & $\mathrm{Y} 1$ & 0,665 & 0.198 & Valid \\
\cline { 2 - 5 } & $\mathrm{Y} 2$ & 0,727 & 0.198 & Valid \\
\cline { 2 - 5 } & $\mathrm{Y} 3$ & 0,765 & 0.198 & Valid \\
\cline { 2 - 5 } & $\mathrm{Y} 4$ & 0,740 & 0.198 & Valid \\
\hline
\end{tabular}

Sumber : Data Primer Diolah (2018)

Hasil tersebut di atas menunjukkan bahwa butir-butir kuesioner dalam penelitian ini adalah valid hal ini ditunjukkan dengan nilai $r$ hitung pada masing-masing item lebih besar dari $r$ tabel (0.198), artinya seluruh butir pertanyaan dapat digunakan sebagai instrumen penelitian.

\section{Uji Reliabilitas}

Pengujian kehandalan ditunjukkan untuk menguji sejauh mana hasil pengukuran dapat dipercaya.Tinggi rendahnya keandalan digambarkan melalui koefisien reliabilitas dalam suatu rangka tertentu.Dalam pengujian pengetahuan digunakan tes konsistensi internal yaitu sistem pengujian terhadap sekelompok tertentu, kemudian dihitung skornya dan diuji konsistensinya terhadap berbagai item yang ada dalam kelompok tersebut. Nilai koefisien alpha bervariasi mulai dari 0 (nol) sampai dengan 1 (satu) dan untuk nilai alphanya $=0,60$ atau kurang memberi indikasi bahwa alat ukur tersebut kurang kehandalannya.

Tabel-IV.3

Reliabilitas Variabel Penelitian Alpha

\begin{tabular}{|c|l|c|c|c|}
\hline $\begin{array}{c}\text { N } \\
\text { o }\end{array}$ & \multicolumn{1}{|c|}{ Variabel } & $\begin{array}{c}\text { Item } \\
\text { Variabel }\end{array}$ & $\begin{array}{c}\text { Nilai } \\
\text { Alpha }\end{array}$ & $\begin{array}{c}\text { Kehand } \\
\text { alan }\end{array}$ \\
\hline 1 & Pengetahuan & 3 & 0,641 & Handal \\
\hline 2 & Keterampilan & 3 & 0,638 & Handal \\
\hline 3 & Perilaku & 3 & 0,725 & Handal \\
\hline 4 & Pengalaman kerja & 3 & 0,601 & Handal \\
\hline 5 & Kinerja pegawai & 4 & 0,691 & Handal \\
\hline
\end{tabular}

Sumber : Data Primer Diolah (2018)
Berdasarkan tabel 4.3 diatas dapat diketahui bahwa alpha untuk masing-masing variabel yaitu variabel Pengetahuan (X1) diperoleh nilai alpha sebesar 0,641 , variabel Keterampilan (X2) diperoleh nilai alpha sebesar 0,638, variabel Perilaku (X3) diperoleh nilai alpha sebesar 0,725, variabel Pengalaman Kerja (X4) diperoleh nilai alpha sebesar 0,601 dan variabel Kinerja Pegawai (Y) diperoleh nilai alpha sebesar 0,691. Dengan demikian pengukuran reliabilitas terhadap variabel penelitian menunjukkan bahwa pengukuran kehandalan memenuhi syarat reliabilitas atau dengan kata lain bahwa kuesioner ini reliabel sebagai instrumen penelitian.

\section{Analisis Pengujian Asumsi Klasik Uji Normalitas}

Uji normalitas digunakan untuk menguji apakah data dari sampel yang diambil normal atau tidak. Residual variabel yang terdistribusi normal yang akan terletak di sekitar garis horizontal (tidak terpisah jauh dari garis diagonal).Berdasarkan P-Plot pada lampiran menunjukkan sebaran standarrized residual berada dalam kisaran garis diagonal. Seperti terlihat pada gambar berikut :

Normalitas dapat juga dilihat melalui uji Kolmogorov-smirnov Z, apabila probabilitas Kolmogorov-Smirnov $\mathrm{Z}>0,05$, maka data penelitian mempunyai distribusi normal. Berdasarkan pengujian Kolmogorov-Smirnov Z, menunjukkan bahwa probabilitas KolmogorovSmirnov $Z>0,05$. Ini berarti data penelitian ini mempunyai distribusi normal dengan perinciannya sebagai berikut :

a. Variabel Pengetahuan (X1) dengan probabilitas Kolmogorov-Smirnov Z $0,936>0,05$.

b. Variabel Keterampilan (X2) dengan probabilitas Kolmogorov-Smirnov Z $0,909>0,05$

c. Variabel Perilaku (X3) dengan probabilitas Kolmogorov-Smirnov Z

$1,016>0,05$

d. Variabel Pengalaman Kerja (X4) dengan probabilitas Kolmogorov-Smirnov Z1,010 > 0,05 
e. Variabel Kinerja Pegawai (Y) dengan probabilitas Kolmogorov-Smirnov Z1,003 > 0,05

\section{Uji Multikolinearitas}

Multikolinearitas diuji dengan melihat VIF dari masing-masing variabel independen terhadap variabel dependen.Bila VIF $<10$ maka tidak terjadi multikolinearitas atau no multikolinearitas artinya data yang diteliti tidak terdapat pengaruh variabel luar yang dapat merusak kualitas data yang diperoleh. Hasil pengujian ditunjukkan pada tabel berikut :

Tabel-IV.4

Nilai VIF Variabel Bebas

\begin{tabular}{|l|c|c|}
\hline Variabel Bebas & VIF & Keterangan \\
\hline Pengetahuan & 3.832 & Non Multikolinearitas \\
\hline Keterampilan & 3.796 & Non Multikolinearitas \\
\hline Perlaku & 4.140 & Non Multikolinearitas \\
\hline Pengalaman Kerja & 5.823 & Non Multikolinearitas \\
\hline
\end{tabular}

Sumber : Data Primer Diolah (2018)

Berdasarkan tabel diatas dapat dijelaskan bahwa semua indikator dalam penelitian ini telah bebas adanya variabel pengganggu yang dapat mengurangi validitas hasil penelitian, karena diperoleh nilai multikolinearitas berasarkan nilai VIF (Variance Infllting Factor ) lebih kecil dari nilai 10.

\section{Uji Heteroskedastisitas}

Pengujian heteroskedastisitas bertujuan untuk menguji apakah dalam model regresi terjadi ketidaksamaan variance dari residual satu pengamatan ke pengamatan yang lain. Jika variance dari resiudal satu pengamatan ke pengamatan lain tetap maka disebut homoskedastisitas dan jika berbeda disebut heteroskedastisitas. Model regresi yang baik adalah yang homoskedastisitas atau tidak terjadi heteroskedastisitas. Deteksi ada tidaknya heteroskedastisitas dapat dilakukan dengan melihat ada tidaknya pola tertentu pada grafik scatter plot.
Jika ada pola tertentu, seperti titik-titik yang ada membentuk pola tertentu yang teratur (bergelombang, melebar kemudian menyempit), maka mengidentifikasikan telah terjadi heteroskedastisitas.Jika tidak ada pola yang jelas, serta titik-titik menyebar diatas dan dibawah angka 0 pada sumbu Y maka tidak terjadi heteroskedastisitas. Hasil pengolahan data menunjukkan grafik scatter plot seperti terlihat sebagai berikut :

\section{Pembahasan}

\section{Pengaruh Kompetensi Terhadap Kinerja Pegawai pada Puskesmas Kecamatan Darussalam Kabupaten Aceh Besar}

Untuk mengetahui pengaruh variabel Pengetahuan, Keterampilan, Perilaku, dan Pengalaman Kerja terhadap Kinerja Pegawai pada Puskesmas Kecamatan Darussalam Kabupaten Aceh Besar, maka dilakukan analisis data melalui regresi linear berganda. Dimana hasilnya dapat dilihat pada Tabel-IV.5berikut :

\section{Tabel-IV.5}

Pengaruh Masing-masing Variabel Independen Terhadap Variabel Dependen

\begin{tabular}{|c|c|c|c|c|c|c|}
\hline $\begin{array}{c}\text { Nama } \\
\text { Variabel }\end{array}$ & B & $\begin{array}{c}\text { Stand } \\
\text { ar } \\
\text { Error }\end{array}$ & $\begin{array}{c}\text { Bet } \\
\text { a }\end{array}$ & $\mathbf{t}_{\text {hitung }}$ & $t_{\text {tabel }}$ & Sign \\
\hline Konstanta & $\begin{array}{r}1.58 \\
1\end{array}$ & .463 & & $\begin{array}{r}3.41 \\
2\end{array}$ & $\begin{array}{c}1,66 \\
2\end{array}$ & .001 \\
\hline $\begin{array}{l}\text { Pengetahua } \\
\mathrm{n}\end{array}$ & .268 & .077 & $\begin{array}{r}.24 \\
8\end{array}$ & $\begin{array}{r}3.48 \\
4\end{array}$ & $\begin{array}{c}1,66 \\
2\end{array}$ & .001 \\
\hline $\begin{array}{l}\text { Keterampila } \\
\mathrm{n}\end{array}$ & .232 & .075 & $\begin{array}{r}.22 \\
0\end{array}$ & $\begin{array}{r}3.11 \\
1\end{array}$ & $\begin{array}{c}1,66 \\
2\end{array}$ & .003 \\
\hline Perilaku & .232 & .079 & $\begin{array}{r}.21 \\
6\end{array}$ & $\begin{array}{r}2.92 \\
8\end{array}$ & $\begin{array}{c}1,66 \\
2\end{array}$ & .005 \\
\hline $\begin{array}{l}\text { Pengalaman } \\
\text { Kerja }\end{array}$ & .430 & .108 & $\begin{array}{r}.34 \\
7\end{array}$ & $\begin{array}{r}3.96 \\
4\end{array}$ & $\begin{array}{c}1,66 \\
2\end{array}$ & .000 \\
\hline \multicolumn{7}{|c|}{$\begin{array}{lr}\text { Koefisien Korelasi }(\mathrm{R}) & =0,96 \\
\text { Koefisien Determinasi }\left(\mathrm{R}^{2}\right) & =0,92 \\
\text { Adjusted R Squares } & =0,918 \\
\mathrm{~F}_{\text {hitung }}=175.092 & \\
\mathrm{~F}_{\text {tabel }}=2,47 & \\
\text { Sign } \mathrm{F}=0,000 & \end{array}$} \\
\hline
\end{tabular}

Sumber :Data Primer Penelitian Diolah (2018)

Dari output SPSS di atas dengan dipergunakan model regresi berganda, dapat difungsikan dalam bentuk persamaan sebagai berikut :

$\mathrm{Y}=1.581+0.268 \mathrm{X} 1+0.232 \mathrm{X} 2+0.232 \mathrm{X} 3+$ $0.430 \mathrm{X} 4$ 
Dari persamaan regresi linear berganda di atas dapat dijelaskan sebagai berikut :

a. Nilai konstanta sebesar 1.581 artinya jika Pengetahuan (X1), Keterampilan (X2), Perilaku (X3) dan Pengalaman Kerja (X4), dianggap konstan, maka Kinerja pegawai pada Puskesmas Kecamatan Darussalam Kabupaten Aceh Besar adalah sebesar 1.581 .

b. Nilai koefisien regresi Pengetahuan sebesar 0.268 dapat diartikan bahwa setiap $1 \%$ kenaikan Pengetahuan (X1) maka akan meningkatkan Kinerja Pegawai pada Puskesmas Kecamatan Darussalam Kabupaten Aceh Besar sebesar 0,268\%. Ini berarti terjadi Kinerja Pegawai pada Puskesmas Kecamatan Darussalam Kabupaten Aceh Besar.

c. Nilai koefisien regresi Keterampilan sebesar 0.232 dapat diartikan bahwa setiap $1 \%$ kenaikan Keterampilan (X2) maka akan meningkatkan Kinerja Pegawai pada Puskesmas Kecamatan Darussalam Kabupaten Aceh Besar sebesar 0.232\%. Ini berarti terjadi Kinerja pegawai pada Puskesmas Kecamatan Darussalam Kabupaten Aceh Besar.

d. Nilai koefisien regresi Perilaku sebesar 0.232 dapat diartikan bahwa setiap $1 \%$ kenaikan Perilaku (X3) maka akan meningkatkan Kinerja Pegawai pada Puskesmas Kecamatan Darussalam Kabupaten Aceh Besar sebesar 0.232\%. Ini berarti terjadi Kinerja pegawai pada Puskesmas Kecamatan Darussalam Kabupaten Aceh Besar.

e. Nilai koefisien regresi Pengalaman Kerja sebesar 0.430 dapat diartikan bahwa setiap $1 \%$ kenaikan Pengalaman Kerja (X4) maka akan meningkatkan Kinerja Pegawai pada Puskesmas Kecamatan Darussalam Kabupaten Aceh Besar sebesar 0.430\%. Ini berarti terjadi Kinerja pegawai pada Puskesmas Kecamatan Darussalam Kabupaten Aceh Besar.
Berdasarkan hasil analisis di atas dapat disimpulkan bahwa dari keempat variabel yang diteliti, ternyata variabel Pengalaman Kerja (X4) mempunyai pengaruh yang paling dominan sebesar $0.430 \%$ terhadap Kinerja Pegawai pada Puskesmas Kecamatan Darussalam Kabupaten Aceh Besar.

Hubungan antara variabel dependen dan independen yaitu masing-masing variabel Pengetahuan (X1), Keterampilan (X2), Perilaku (X3), dan Pengalaman Kerja (X4) terhadap Kinerja Pegawai pada Puskesmas Kecamatan Darussalam Kabupaten Aceh Besar dengan indeks korelasi sebesar 0,961 ini berarti hubungan tersebut sangat kuat karena hampir mendekati 1.

Kemudian indeks determinasi masingmasing variabel Pengetahuan (X1), Keterampilan (X2), Perilaku (X3), dan Pengalaman Kerja (X4) sebesar 0,924 \% ini berarti keempat variabel berpengaruh secara signifikan terhadap Kinerja Pegawai pada Puskesmas Kecamatan Darussalam Kabupaten Aceh Besar, dan sebesar 7,6\% yang dipengaruhi oleh variabel lain yang tidak diteliti dalam penelitian ini.

\section{Hasil Pengujian Hipotesis Uji F}

Uji serempak atau Uji F merupakan uji secara bersama-sama untuk menguji signifikansi pengaruh variabel Pengetahuan (X1), Keterampilan (X2), Perilaku (X3) dan Pengalaman Kerja (X4) terhadap variabel Kinerja Pegawai (Y). Uji F dilakukan untuk melihat pengaruh variabel independen terhadap variabel dependen secara bersama-sama (secara simultan). Pembuktiannya dapat dijelaskan sebagai berikut :

\begin{tabular}{|c|r|r|r|r|r|r|r|}
\hline \multicolumn{2}{|c|}{ Model } & $\begin{array}{c}\text { Sum of } \\
\text { Squares }\end{array}$ & Df & $\begin{array}{c}\text { Mean } \\
\text { Squar } \\
\text { e }\end{array}$ & F & F $_{\text {tabel }}$ & Sig. \\
\hline 1 & Regression & 220.179 & 4 & 55.045 & 175.092 & 2,47 & 0,000 \\
\hline Residual & 18.234 & 58 & .314 & & & \\
\hline Total & 238.413 & 62 & & & & \\
\hline
\end{tabular}

Sumber : Data Primer Penelitian Diolah (2018) 
Hasil pengujian secara simultan diperoleh Fhitung 175.092> Ftabel 2,47 . Dengan demikian hasil perhitungan ini dapat diambil suatu keputusan bahwa menerima hipotesis alternatif (Ha) dan menolak hipotesis nol (Ho), artinya bahwa variabel Pengetahuan (X1), Keterampilan (X2), Perilaku (X3), dan Pengalaman Kerja (X4), secara bersama-sama berpengaruh secara signifikan terhadap Kinerja Pegawai pada Puskesmas Kecamatan Darussalam Kabupaten Aceh Besar.

\section{Uji t}

Pengujian ini untuk melihat sejauh mana pengaruh secara terpisah dari masing-masing variabel Pengetahuan (X1), Keterampilan (X2), Perilaku (X3), dan Pengalaman Kerja (X4) terhadap variabel terikat $(\mathrm{Y})$ berdasarkan hasil regresi yang ada, Uji t dilakukan dengan membandingkan nilai t hitung dengan $\mathrm{t}$ tabel dengan tingkat kesalahan 5\%. Uji t dilakukan untuk melihat signifikan dari pengaruh variabel independen secara individu terhadap variabel dependen (Secara parsial). Pembuktian hipotesis secara parsial dapat dijelaskan seperti table-IV.7 di bawah ini, maka dapat disajikan sebagai berikut :

Tabel-IV.7

Hasil Analisis Uji t

\begin{tabular}{|c|c|c|c|c|c|c|c|}
\hline & \multirow[t]{2}{*}{ Model } & \multicolumn{2}{|c|}{$\begin{array}{c}\text { Unstandarriz } \\
\text { ed } \\
\text { Coefficients }\end{array}$} & \multirow{2}{*}{\begin{tabular}{c} 
Stand \\
arrize \\
d \\
Coeff \\
icient \\
\multicolumn{5}{c}{} \\
Beta
\end{tabular}} & \multirow[t]{2}{*}{$t_{\text {hitung }}$} & \multirow[t]{2}{*}{$t_{\text {tabel }}$} & \multirow[t]{2}{*}{ Sig. } \\
\hline & & B & $\begin{array}{l}\text { Std. } \\
\text { Error }\end{array}$ & & & & \\
\hline \multirow[t]{5}{*}{$\overline{1}$} & Konstanta & $\begin{array}{c}1.58 \\
1\end{array}$ & .463 & & 3.412 & 1,662 & .001 \\
\hline & $\begin{array}{l}\text { Pengetahua } \\
\mathrm{n}\end{array}$ & .268 & .077 & .248 & 3.484 & 1,662 & .001 \\
\hline & $\begin{array}{l}\text { Keterampila } \\
\mathrm{n}\end{array}$ & .232 & .075 & .220 & 3.111 & 1,662 & .003 \\
\hline & Perilaku & .232 & .079 & .216 & 2.928 & 1,662 & .005 \\
\hline & $\begin{array}{l}\text { Pengalaman } \\
\text { Kerja }\end{array}$ & .430 & .108 & .347 & 3.964 & 1,662 & .000 \\
\hline
\end{tabular}

Sumber : Data Primer Penelitian Diolah (2018)

a. Variabel Pengetahuan (X1) diperoleh thitung $3.484>$ ttabel 1,662 dan nilai signifikan $0.001<0.05$, sehingga Hipotesis
Nol (Ho) diterima dan Hipotesis Alternatif (Ha) ditolak. Dari hasil uji $\mathrm{t}$ ini dapat disimpulkan bahwa variabel Pengetahuan (X1) berpengaruh secara signifikan terhadap Kinerja Pegawai pada Puskesmas Kecamatan Darussalam Kabupaten Aceh Besar.

b. Variabel Keterampilan (X2) diperoleh thitung 3.111> ttabel 1,662 dan nilai signifikan 0.003>0.05, sehingga Hipotesis Nol (Ho) ditolak dan Hipotesis Alternatif (Ha) diterima. Dari hasil uji $\mathrm{t}$ ini dapat disimpulkan bahwa variabel Keterampilan (X2) berpengaruh secara signifikan terhadap Kinerja Pegawai pada Puskesmas Kecamatan Darussalam Kabupaten Aceh Besar.

c. Variabel Perilaku (X3) diperoleh thitung 2.928> ttabel 1,662 dan nilai signifikan $0.005=0.05$, sehingga Hipotesis Nol $(\mathrm{Ho})$ ditolak dan Hipotesis Alternatif (Ha) diterima. Dari hasil uji $\mathrm{t}$ ini dapat disimpulkan bahwa variabel Perilaku (X3) berpengaruh secara signifikan terhadap Kinerja Pegawai pada Puskesmas Kecamatan Darussalam Kabupaten Aceh Besar.

d. Variabel Pengalaman Kerja (X4) diperoleh thitung $3.964>$ ttabel 1,662 dan nilai signifikan $0.000<0.05$, sehingga Hipotesis Nol (Ho) ditolak dan Hipotesis Alternatif (Ha) diterima. Dari hasil uji $\mathrm{t}$ ini dapat disimpulkan bahwa variabel Pengalaman Kerja (X4) berpengaruh secara signifikan terhadap Kinerja Pegawai pada Puskesmas Kecamatan Darussalam Kabupaten Aceh Besar.

\section{Kesimpulan}

Kesimpulan dari hasil penelitian tentang "Pengaruh Kompetensi Terhadap Kinerja Pegawai Pada Puskesmas Kecamatan Darussalam Kabupaten Aceh Besar" adalah sebagai berikut :

1. Berdasarkan hasil analisis di atas dapat disimpulkan bahwa dari keempat variabel 
yang diteliti, ternyata variabel pengalaman kerja (X4) mempunyai pengaruh yang paling dominan sebesar $0.430 \%$ terhadap Kinerja pegawai pada Puskesmas Kecamatan Darussalam Kabupaten Aceh Besar.

2. Hubungan antara variabel dependen dan independen yaitu masing-masing variabel Pengetahuan (X1), Keterampilan (X2), Perilaku (X3) dan Pengalaman Kerja (X4) terhadap Kinerja pegawai pada Puskesmas Kecamatan Darussalam Kabupaten Aceh Besar dengan indeks korelasi sebesar 0,961 ini berarti hubungan tersebut sangat kuat karena sudah mendekati 1.

3. Kemudian indeks determinasi (R2)masingmasing variabel Pengetahuan (X1), Keterampilan (X2), Perilaku (X3) dan Pengalaman Kerja (X4) sebesar 0,924\%, ini berarti keempat variabel berpengaruh secara signifikan terhadap Kinerja Pegawai pada Puskesmas Kecamatan Darussalam Kabupaten Aceh Besar, dan sebesar 7,6\% yang dipengaruhi oleh variabel lain yang tidak diteliti dalam penelitian ini.

4. Hasil pengujian secara simultan diperoleh Fhitung 175.092> Ftabel 2,47 . Dengan demikian hasil perhitungan ini dapat diambil suatu keputusan bahwa menerima hipotesis alternatif (Ha) dan menolak hipotesis nol (Ho), artinya bahwa variabel Pengetahuan (X1), Keterampilan (X2), Perilaku (X3), dan Pengalaman Kerja (X4), secara bersama-sama berpengaruh secara signifikan terhadap Kinerja Pegawai pada Puskesmas Kecamatan Darussalam Kabupaten Aceh Besar.

5. Variabel Pengetahuan (X1) diperoleh thitung $3.484>$ ttabel 1,662 dan nilai signifikan $0.001<0.05$, sehingga Hipotesis Nol (Ho) diterima dan Hipotesis Alternatif (Ha) ditolak. Dari hasil uji t ini dapat disimpulkan bahwa variabel Pengetahuan (X1) berpengaruh secara signifikan terhadap Kinerja Pegawai pada Puskesmas
Kecamatan Darussalam Kabupaten Aceh Besar.

6. Variabel Keterampilan (X2) diperoleh thitung $3.111>$ ttabel 1,662 dan nilai signifikan $0.003>0.05$, sehingga Hipotesis Nol (Ho) ditolak dan Hipotesis Alternatif (Ha) diterima. Dari hasil uji $t$ ini dapat disimpulkan bahwa variabel Keterampilan (X2) berpengaruh secara signifikan terhadap Kinerja Pegawai pada Puskesmas Kecamatan Darussalam Kabupaten Aceh Besar.

7. Variabel Perilaku (X3) diperoleh thitung $2.928>$ ttabel 1,662 dan nilai signifikan $0.005=0.05$, sehingga Hipotesis Nol $(\mathrm{Ho})$ ditolak dan Hipotesis Alternatif (Ha) diterima. Dari hasil uji $t$ ini dapat disimpulkan bahwa variabel Perilaku (X3) berpengaruh secara signifikan terhadap Kinerja Pegawai pada Puskesmas Kecamatan Darussalam Kabupaten Aceh Besar.

8. Variabel Pengalaman Kerja (X4) diperoleh thitung $3.964>$ ttabel 1,662 dan nilai signifikan $0.000<0.05$, sehingga Hipotesis Nol (Ho) ditolak dan Hipotesis Alternatif (Ha) diterima. Dari hasil uji $t$ ini dapat disimpulkan bahwa variabel Pengalaman Kerja (X4) berpengaruh secara signifikan terhadap Kinerja Pegawai pada Puskesmas Kecamatan Darussalam Kabupaten Aceh Besar.

\section{Saran-saran}

Adapun saran-saran yang dapat diambil dari hasil penelitian ini adalah sebagai berikut:

1. Untuk meningkatkan kinerja pegawai pada Puskesmas Kecamatan Darussalam Kabupaten Aceh Besar, sebaiknya kepala Puskesmas harus lebih memperhatikan dan fokus terhadap peningkatan kompetensi pegawainya.

2. Untuk menciptakan kinerja pegawai yang sesuai harapan, sebaiknya dalam perekrutan pegawai harus melakukan seleksi dengan benar terhadap kompetensi 
pegawai dan lebih professional dalam menyeleksinya.

\section{DAFTAR PUSTAKA}

Akdon dan Riduan. 2007, Rumus dan Data Dalam Analisis Statistika, cetakan kedua, Bandung: Alfabeta.

Amstrong, M., \& Murlis, H. 2007, Pedoman Praktis Sistem Penggajian,Jakarta : Pustaka Binaman Pressindo.

Arikunto, Suharsimi. 2010. Prosedur Penelitian (Suatu Pendekatan Praktek) EdisiEnam, Jakarta :Rineka Cipta.

Dessler, Garry. 2008. Human Resource Management. Fourth Edition, New. Jersey:Prentice Hall Internasional.

Dunnett, S.B. 2007. Motor Coordination and Balance in Rodents. Current ProtocolsIn Neuroscience. USA: New Jersey.

Hutapea, Parulian \& Nurianna Thoha. 2008. Kompetensi Plus. Jakarta: Gramedia Pustaka Utama.

Mangkunegara, AA. Prabu. 2008. Manajemen Sumber Daya Manusia Perusahaan. Bandung: Remaja Rosdakarya.

Manullang. M. Marihot. 2008. Manajemen Personalia. Yogyakarta: Gajah Mada University Press.

Makawi, Umar, dkk. 2015. Analisis Pengaruh Kompetensi terhadap Kinerja Pegawai Dinas Perindustrian dan Perdagangan Kota Banjarmasin. Jurnal Al - Ulum Ilmu Sosialdan HUMANIORA ISSN: 2476 - 9576 Volume 1 Nomor 1, Oktober 2015

Mathis, R \& Jackson, W. 2006.Human Resources Development (Track MBA Series/terjemahan).Jakarta; Prestasi Pustaka.

Monks, F.J., Knoers, A.M.P \& Hadinoto S.R. 2008, Psikologi Perkembangan:

Pengantar Dalam Berbagai Bagiannya. Yogyakarta: Gadjah Mada University Press.
Ruky, Achmad S. 2006. Sistem Manajemen Kinerja. Jakarta : Bumi Aksara.

Saiful, Muhammad.2012. Pengaruh Pengetahuan dan Pengalaman Kerja TerhadapKinerja Pegawai pada Rumah Sakit Umum RSUZA Banda Aceh.Skripsi. Universitas Syiah Kuala.

Pahlan, R. 2007. Competency Management. Jakarta: PPM.

PP Nomor 13 Tahun 2002 tentang Perubahan atas PP nomor 100 Tahun 2000 Pengangkatan PNS dalam Jabatan Struktural.

PP Nomor 46 Tahun 2011 tentang Penilaian Prestasi Kerja Pegawai.

PERKA BKN Nomor 1 Tahun 2013 tentang Pelaksanaan PP Nomor 462011 tentang Penilaian Prestasi Kerja Pegawai.

Prihadi, S. 2006. Kinerja, Aspek Pengukuran. Jakarta: Gramedia Pustaka.

Sudarmanto. 2009. Kinerja dan Pengembangan Kompetensi SDM Teori, Dimensi dan Implementasi dalam Organisasi.Yogyakarta; Pustaka Pelajar.

Sanusi, Budiman. 2011. Pengembangan Sumber Daya Manusia. Surabaya: Airlangga University Press.

Sugiyono. 2010. Metode Penelitian Bisnis. Bandung : Alfabeta.

Susanto, 2008.Sistem Informasi Manajemen (Konsep Dan Pengembangannya) EdisiTiga, Jakarta : Salemba Empat.

Sutrisno, Edi. 2009. Manajemen Sumber Daya Manusia Edisi Pertama. Jakarta: Kencana Prenada Media Group.

Syukran. 2011. Faktor-faktor Yang Mempengaruhi Kinerja Pegawai Pada Dinas

Kehutanan Provinsi

Aceh.Skripsi.Universitas Syiah Kuala.

Wahjosumidjo, Kepemimpinan dan Motivasi.Jakarta: Raja Garfindo Persada. 
Yuli, Sri Budi Cantika. 2005. Manajemen

Sumber Daya Manusia, Cetakan

Pertama,

Malang: UMM Press.

Yuniarsih \& Suwatno. 2008. Manajemen

Sumber Daya Manusia. Bandung :

Alfabeta. 